\title{
HIV and children
}

Population Council

Follow this and additional works at: https://knowledgecommons.popcouncil.org/ series_newsletters_momentum How does access to this work benefit you? Let us know!

\section{Recommended Citation}

"HIV and children," Momentum newsletter. New York: Population Council, 2009. 


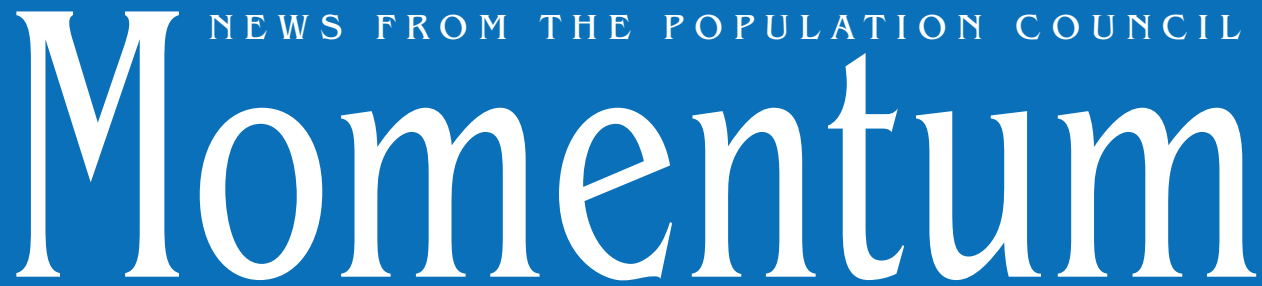

JUNE 2009

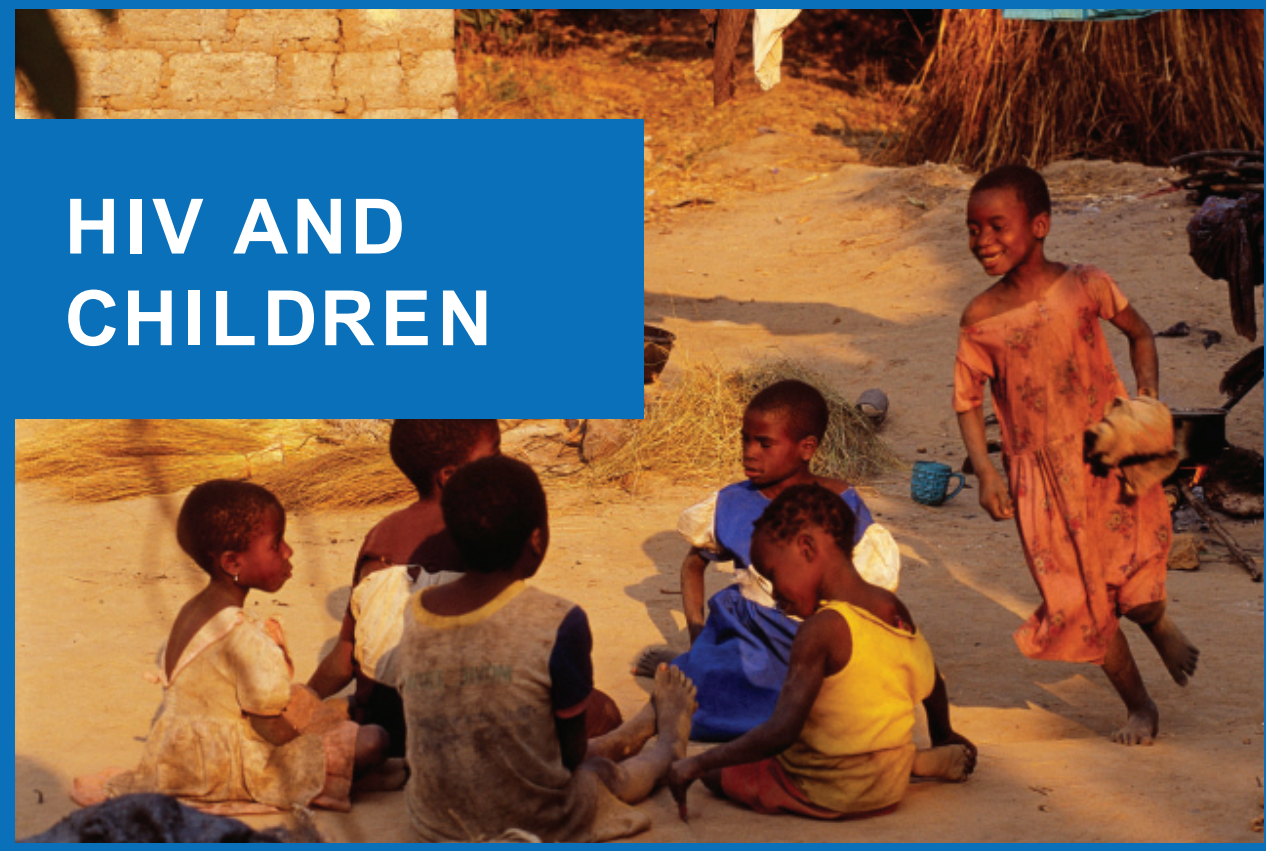

A family of orphaned children plays outside their home in a shanty compound in Kitwe, Zambia

\section{IN THIS ISSUE:}

POPULATION COUNCIL PRESIDENT DISCUSSES OUR WORK HELPING MOTHERS KEEP THEIR BABIES SAFE FROM HIV INCREASING HIV TESTING FOR AT-RISK CHILDREN OVERCOMING BARRIERS TO TREATMENT FOR CHILDREN BUILDING SUPPORT FOR ORPHANS AND VULNERABLE CHILDREN PROFILES: COUNCIL RESEARCHER DR. AVINA SARNA AND TRUSTEE JUSTIN ROCKEFELLER 


\section{$90 \%$}

PERCENTAGE OF CHILDREN WHO DIED OF AIDS IN 2007 WHO LIVED IN

SUB-SAHARAN AFRICA

\section{0,000}

NUMBER OF HIV-INFECTED CHILDREN WORLDWIDE UNDER AGE 15 WHO DIED BECAUSE OF AIDS IN 2007

\section{$43 \%$}

ESTIMATED PERCENTAGE OF PREGNAN WOMEN LIVING WITH HIV IN SOUTH AFRICA WHO DID NOT RECEIVE DRUGS FOR PREVENTING MOTHER-TO-CHILD TRANSMISSION ${ }^{2}$ UNDER AGE 15 WHO BECAME INFECTED WITH HIV IN 2007

\section{$90 \%$}

PERCENTAGE OF CHILDREN LIVING WITH HIV WHO ACQUIRED THE VIRUS DURING MOTHER'S PREGNANCY, BIRTH, OR BREASTFEEDING (ALL PREVENTABLE METHODS OF HIV TRANSMISSION)

\section{$29 \%$}

PERCENTAGE OF PREGNANT WOMEN WHO ARE HIV-POSITIVE IN SOUTH AFRICA ${ }^{3}$
370,000

NUMBER OF CHILDREN WORLDWIDE one or both parents to AIDS. It is hard to fathom the gravity of these numbers except when you think that every one of them-parent or child-was a loved and cared-for family member. Most of these families had no access to treatment for these children. Most probably struggled to give them food and care without any other hope to help them to live longer, healthier lives during their short lifetime.

The Population Council's research and life-saving programs to eliminate HIV infection in newborns and to help HIV-positive children enjoy healthier lives are just two ways that we work to improve the health and well-being of women, men, and children. Our challenge is to get much-needed care to mothers and infants in developing countries who are already infected and to prevent HIV infection for those who are at risk for getting sick. We play a vital role in collaborating with developingcountry partners to help people access life-saving treatment for HIV infection. We work with our in-country counterparts to make programs more effective and widely available so that people who need these services receive them.

This issue of Momentum describes some of the Council's efforts to stop the deaths of children from AIDS. Council research contributed to ongoing initiatives to increase access to drugs that prevent HIV-positive pregnant women from passing the virus to their child (page 2), to provide HIV-positive children with early treatment (pages 4 and 6), and to develop solid evaluation data on current HIV initiatives to help program managers and health care providers strengthen services for individuals and families living with HIV (page 8). Our research expertise provides governments and communities with information needed to increase the effectiveness of programs that support women, newborns, and children affected by HIV and that help them live longer, healthier lives.

Your support helps make this lifesaving work possible. Our programs protect children from the devastating consequences of HIV and AIDS and enable caregivers to offer treatment and hope to young family members who have lost their parents to the disease. Read about one Population Council researcher who gives a personal account of why HIV prevention is so meaningful to her (page 10), and one of our donors (page 11) who talks about why he supports the Council's worldwide work. Your contribution ensures that the Council continues to address these critically important global health concerns and to make life better for current and future generations.

Sincerely,

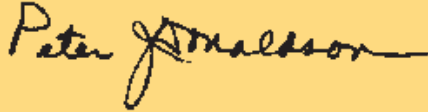

Peter J. Donaldson 


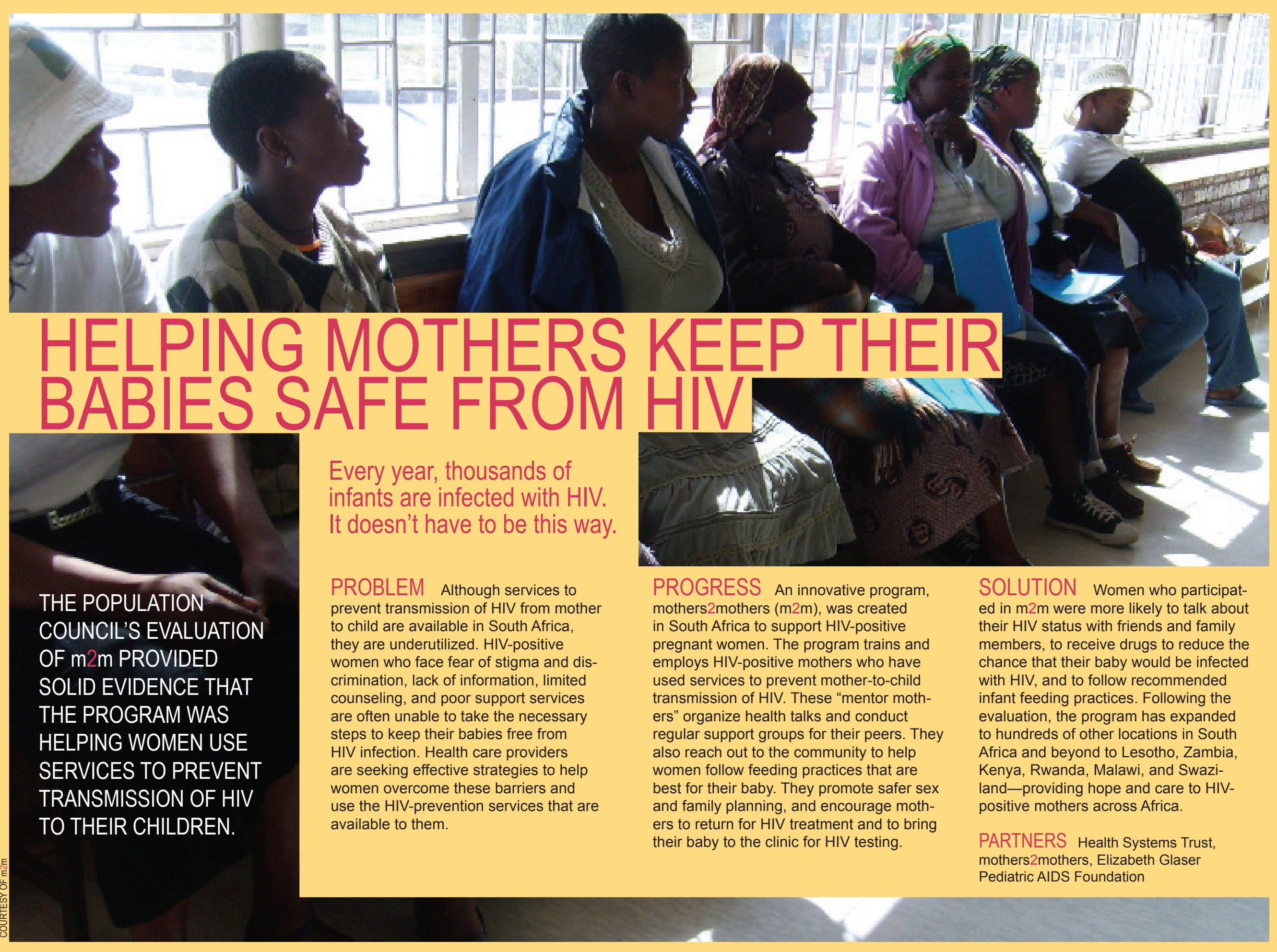




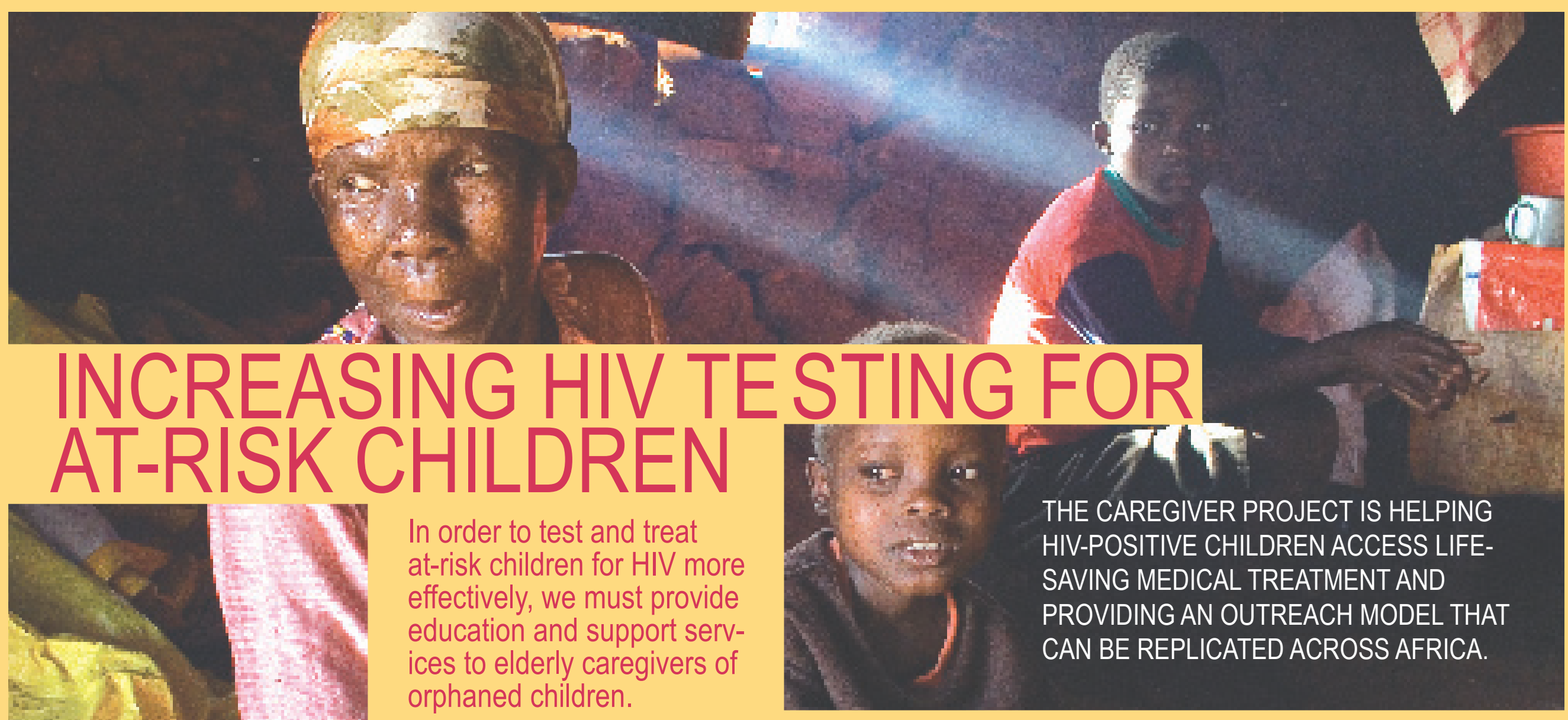

PROBLEM South Africa has the world's largest number of children living with HIV. Many of the most at-risk children live with their grandparents or other relatives. Most caregivers do not know the children's HIV status, since there are few opportunities for testing children after infancy. A life-saving opportunity is lost because children who are diagnosed with and treated for HIV before their immune systems weaken have a much higher chance of survival. Without treatment, HIV-positive children are frequently sick, and caregivers-the elderly in particular-face an overwhelming burden.
PROGRESS The Council developed The Caregiver Project with a local partner, the Masimanyane Women's Support Center. The project trains grandmothers (called "grannies") to serve as peer supporters for elderly caregivers. The grannies provide information about pediatric HIV testing and treatment to elderly caregivers who come to Social Security Agency sites to get grants for social services for children and the elderly. Grannies offer caregivers referral cards that list the locations of pediatric testing services and encourage them to take the children to be tested.
SOLUTION This novel approach of using grannies to promote HIV testing services builds on earlier Council research that demonstrated the critical role elderly caregivers play in caring for children orphaned by HIV. The Caregiver Project is targeting an important gateway to accessing these children, the elderly caregivers, and motivating caregivers to seek care through age-appropriate resources.

PARTNERS South African Social Security Agency, Masimanyane Women's Support Center 


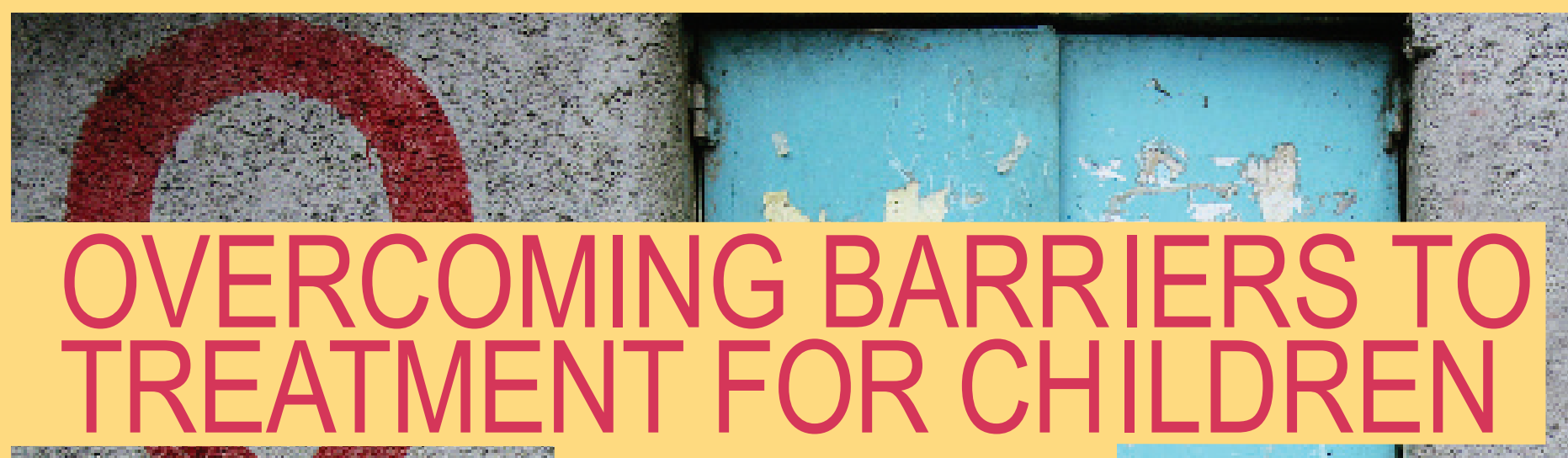

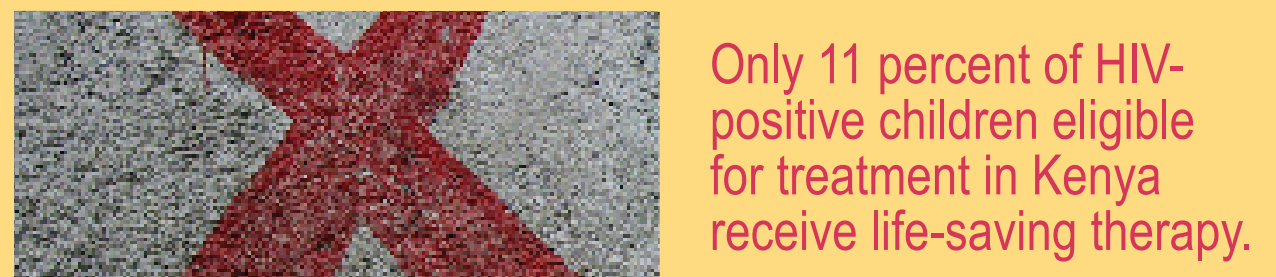

PROBLEM Even in areas where treatment services are available, caregivers of infected children often do not seek care or seek it late in the course of the disease when treatment is less effective.

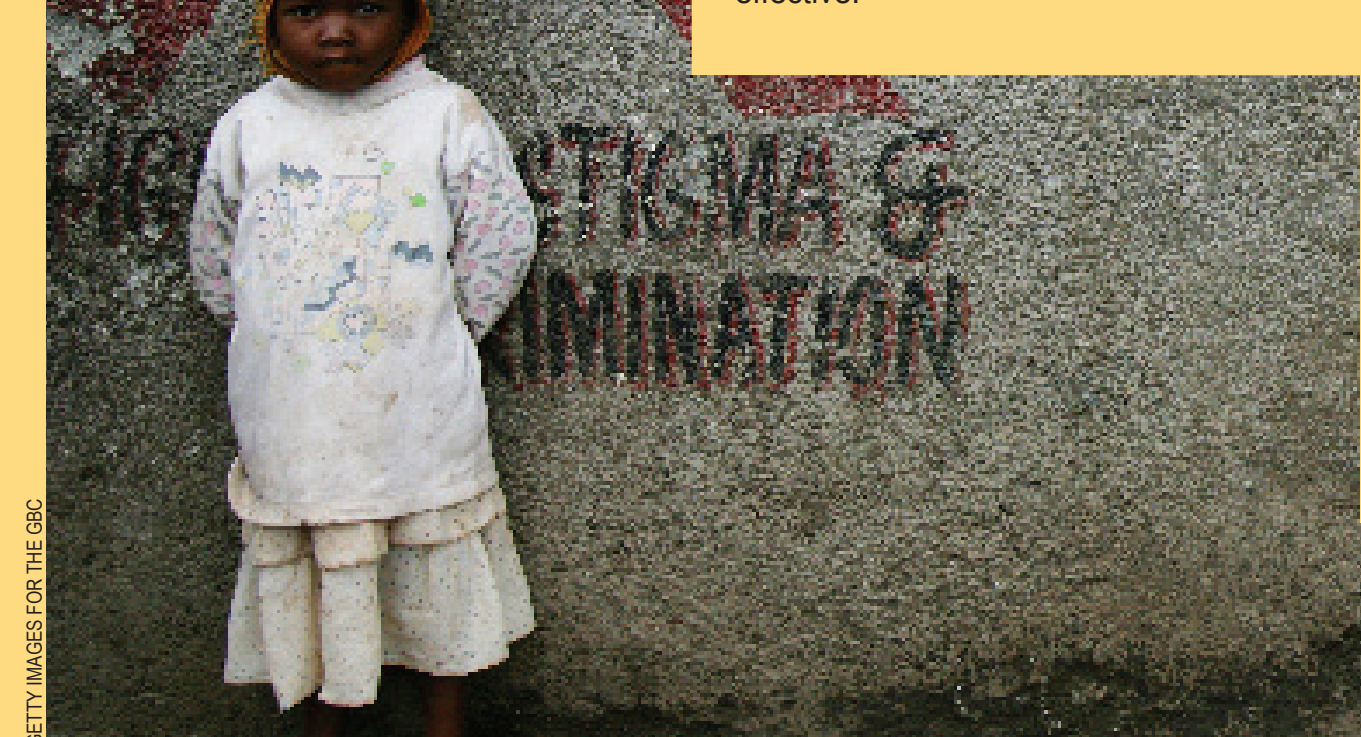

expas ats

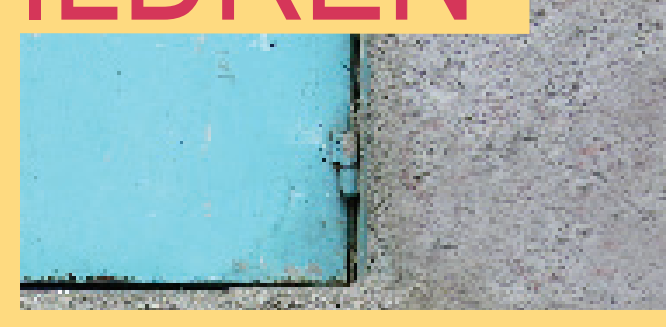

PROGRESS Through surveys, group discussions, and interviews with families and health workers, Council researchers identified barriers that prevent parents and caregivers from seeking treatment for HIV-infected children. Many caregivers were unaware of treatment for children, or were paralyzed by fear and a loss of hope. They worried about additional costs of the free services, including transportation, medicines, food, and consultation fees. They associated the health clinics and treatments with death, since many children who arrived at the clinic with symptoms of HIV infection did not survive. Family members were also often anxious about how others in the community would react if they found out a child in the family was HIV-positive.
AFIER COUNSELING AND BENA GNVEN HOPE THAT: IANDMY CHILECANTAKE. DRUGS AND LIVEON, THE FEAR OF STIGMA HAS

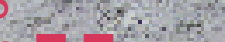
SINCE GROWN JAINGS AND FLOUNAWAY.

- Mother of a child living with HIV who. paricipated in Council research activities

SOLUTION Applying its research findings, the Council and the government of Kenya are supporting community-awareness activities to educate and assist caregivers, inform them of available services, and reduce stigma. The Council is also working with health facilities to improve counseling, support, and outreach services, and to provide Kenya's government with recommendations for improving pediatric HIV services so HIV-positive children across the country receive life-saving treatment.

PARTNERS Christian Health Association of Kenya, Archdiocese of Nairobi Eastern Deanery AIDS Relief Program, Elizabeth Glaser Pediatric AIDS Foundation, Kenya Network of Women with AIDS

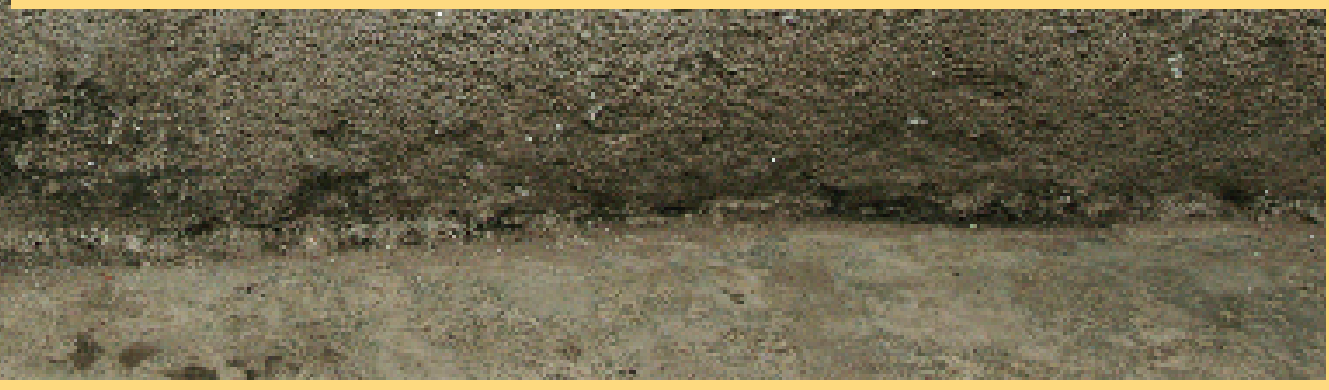


We provide solid scientific evidence about programs targeting orphans and vulnerable children to help governments and communities provide better care for these children in need.

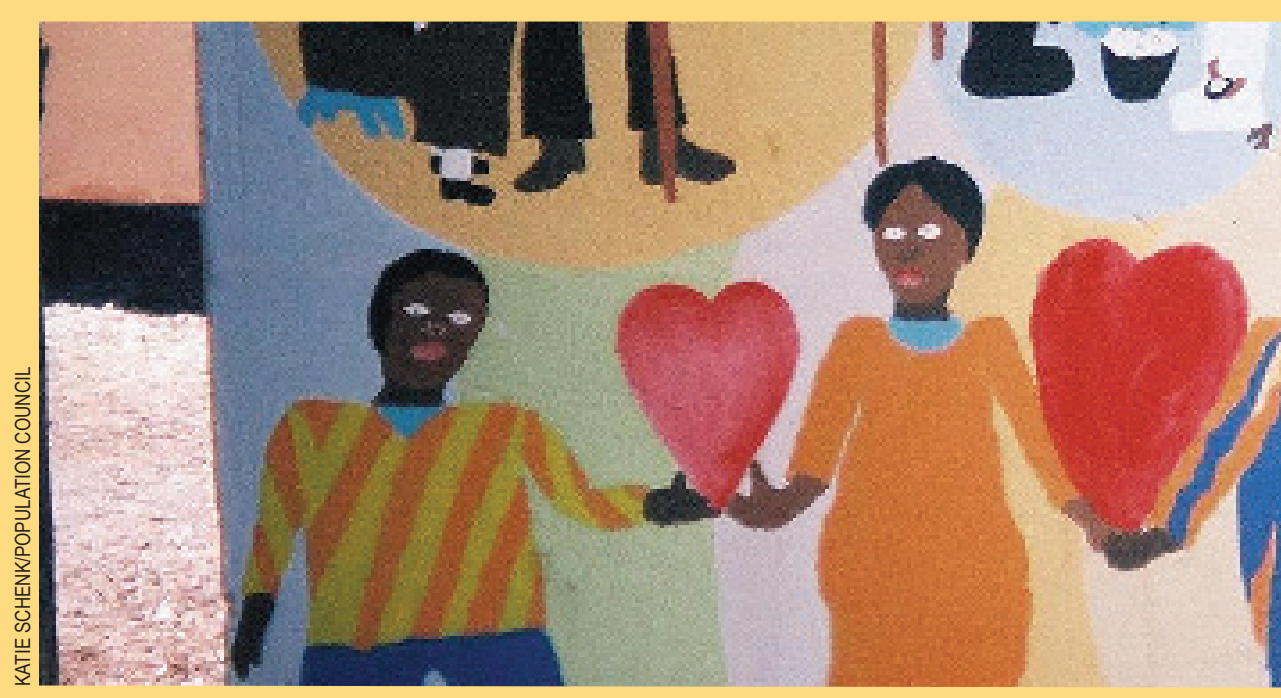

PROBLEM Despite high levels of donor spending with the goal of helping vulnerable children, the evidence for building effective policies and programs remains limited. Without solid evaluation data, policymakers and donors are often forced to make uninformed decisions about the implementation and financing of programs. Program managers and health providers lack information about programs that improve the quality of life for children and families.
PROGRESS Council staff members pioneered the development of definitions of vulnerability to help programs identify the neediest children. A Council evaluation of a program parents plan for their children's future became a UNAIDS "best practice" and has been replicated in many settings. Council researchers are evaluating the RAPIDS program in Zambia. This community-led initiative includes a holistic package of care and support services for people living with HIV and for chilin Uganda that helped HIV-infected

\section{LE} CHILDREN
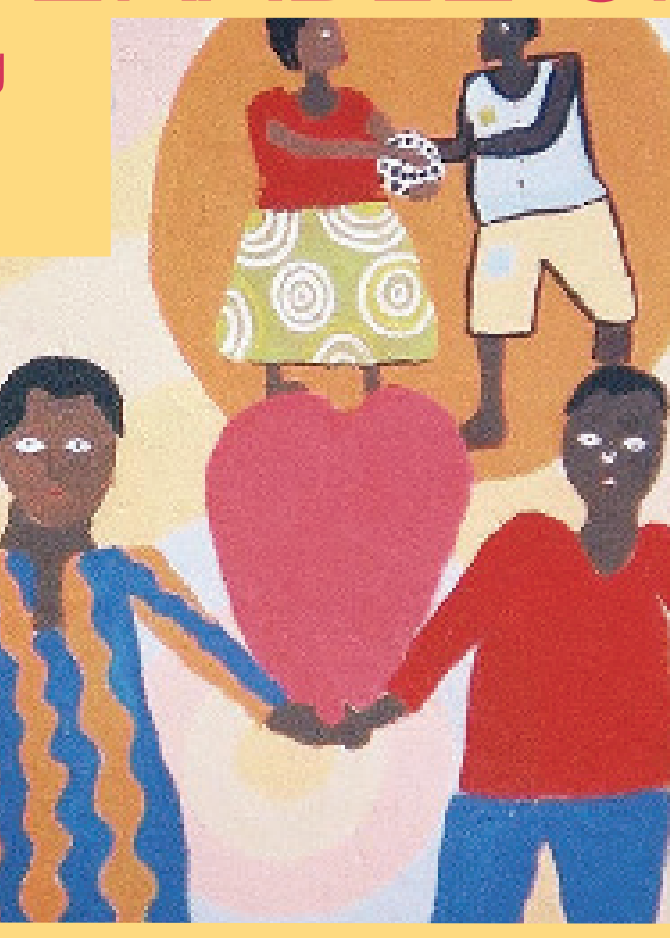

dren living in households and communities affected by HIVIAIDS.

SOLUTION The Council's studies apply innovative research techniques to address complex issues about providing care and services to children affected by HIV. The Council's evaluation of the RAPIDS intervention has highlighted the effectiveness of program activities and valuable lessons for program managers and providers. A mid-term evaluation in 2007 showed important progress, such as more help with school books, uniform

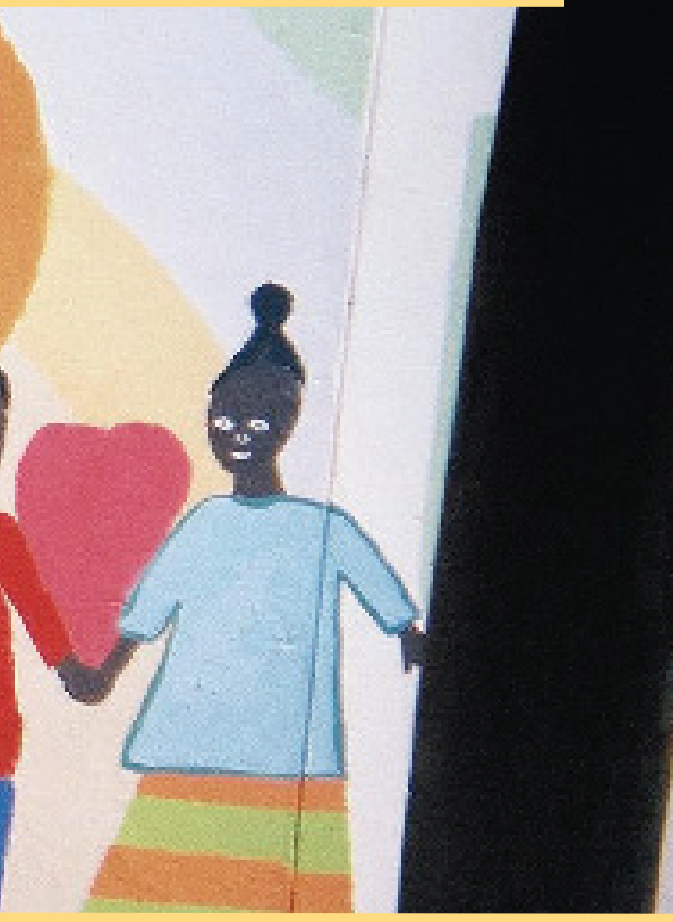

fees, and transportation and improvements in school attendance among vulnerable children. Results from the 2009 data collection promise to provide further guidance to program managers on how to ensure the greatest impact with available resources.

PARTNERS RAPIDS (Africare; CARE Zambia; Catholic Relief Services; Expanded Church Response; RuralNet Associates Ltd, Zambia; The Salvation Army; World Vision; University Teaching Hospital; University of Zambia) 
8

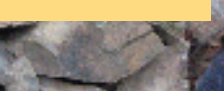

\section{,}

Why is it so difficult to get HIVpositive children treatment and services?

Children cannot advocate for themselves, so when the HIV epidemic first hit communities, all the programs and services focused on adults. It took another three or four years before people realized children needed special treatment, including programs that reached out to parents and caregivers who really controlled the care or lack of care the children received. Caregivers come with their own circumstances and feelings. For example, some parents feel guilty about having infected their children. Some caregivers are uninformed about the disease or worry that they and the children they care for will be isolated from the community if people find out the children have HIV. There is a lot of learning still needed in this area to overcome misinformation and get children the care they need.

Is there a particular family situation that you found especially powerful or memorable? In India, I met a woman who was HIVpositive. She had one child who was HIV-negative but she worried about him and the life he would have once she was gone. She had no one to care for him so she became pregnant again and took precautions to ensure her baby would be HIV-negative. She wanted her son to have a brother or sister so they could look out for one another and take care of each other after she died.

This woman's story is part of what makes my work so rewarding. We need to understand the decisions people make under these very difficult circumstances in order to design programs and services that will help them and their families live longer, healthier lives.

\section{What motivated you to become a} doctor?

I always knew I wanted to be a doctor. There were no doctors in my family; my father was in the Indian military so we moved around a lot to different army bases in India and outside the country. I was born in India but we lived in many other places, including Egypt. Perhaps my mother influenced my interest in medicine. I have always been very focused in my desire to do medicine.

Why did you decide to leave clinical practice for research?

After living and working in many different countries, including Bhutan, Poland, Switzerland, and Iran, I saw systems and programs that worked well in one place and thought these systems and programs could work well in other places too. Being in public health research allows me to help deliver services to more people than I ever could as a physician working one-on-one with patients.

\section{JUSTIN \\ ROCKEFELLER}

\section{COUNCIL TRUSTEE}

For young people like me in a connected, flat world, "the future" is not an abstract concept to be dealt with by our children's children; rather, it is our immediate concern. I proudly support the Population Council because it efficiently improves the lives of young people around the world.

The Council's research includes programs that will help youth and families deal with the consequences of HIV and AIDS. The Poverty, Gender, and Youth program helps girls stay in school, empowers them to make decisions about marriage and pregnancy, and enables them to develop life skills. The Council develops new contraceptives and makes sure they are affordable, safe, and available to both men and women.

I co-founded GenerationEngage, a nonpartisan NGO that empowers young adults (especially those who have not attended a fouryear university) with access and resources to become active citizens and engaged participants in their communities. I have come to know the NGO field quite well, and choose to support the Population Council for the following reasons, among others:

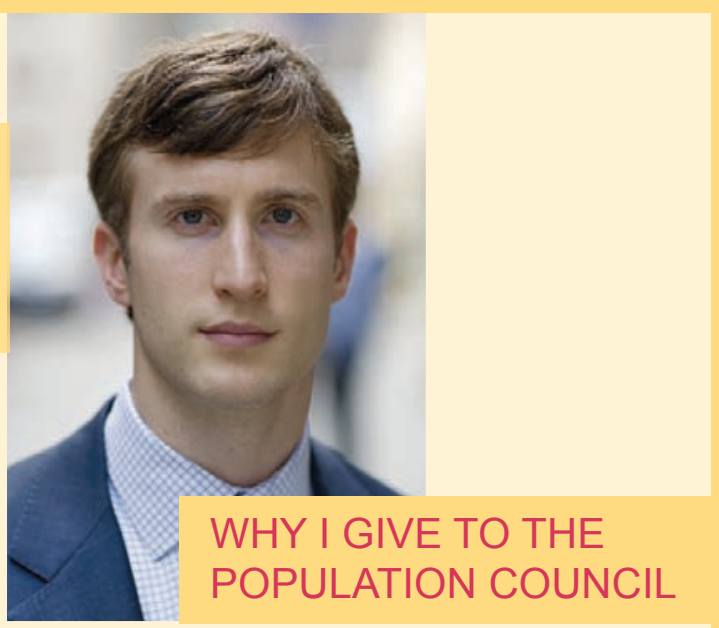

1. Population challenges-not just the number of people but the quality of their lives-lie at the heart of many of the world's great challenges, such as poverty alleviation, climate change, and demand for energy;

2. Through effective collaboration with local and national governments, civil society organizations, NGOs, and communities, the Council's first-rate staff has made a tangible, positive impact on people's lives;

3. The Council educates key decisionmakers about effective policies and programs, then works to help implement those programs; and

4. The Population Council, I have come to see, is very well run. It excels at maximizing the value of every donation.

Please explore the Council's innovative work (www.popcouncil.org) that benefits all of us, then join me in investing in our collective future. 

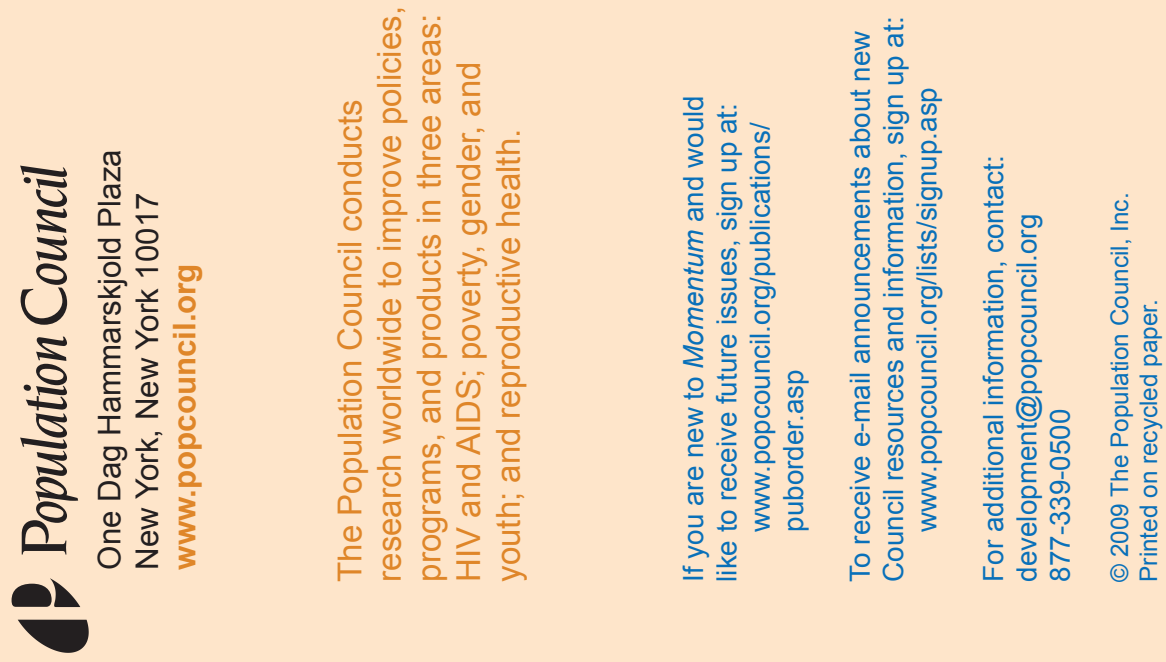